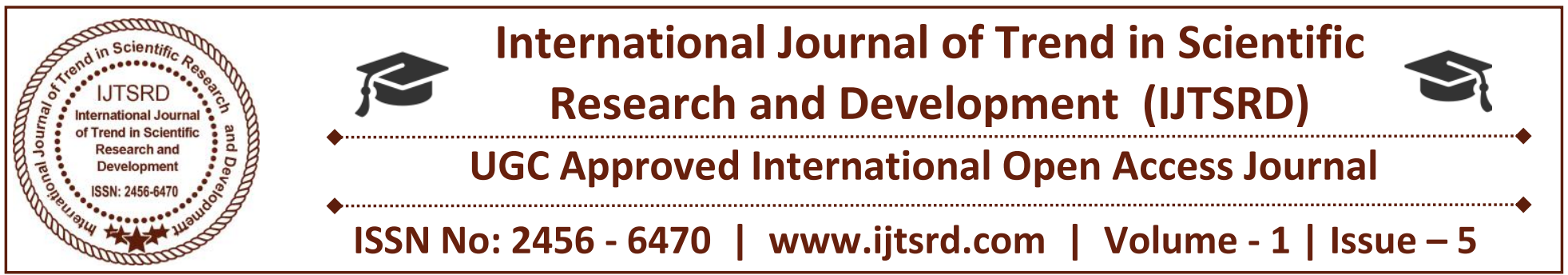

\title{
Hawking and Climate Change: Irreversibility
}

\author{
Jan-Erik Lane
}

\begin{abstract}
As world star physicist Stephen Hawking recently remarked: global warming is close to becoming irreversible. The theory of global warming (GW) could not be more relevant for mankind, as irreversibility probably entails human extinction. Neither the UNFCCC nor the G20 pay enough attention to the dangers of global warming. The COP23, hosted by threated Pacifc Island Fiji, must come up with the means and tools of decarbonisation, as $\mathrm{CO} 2$ emissions must be reduced. Solar power parks will do, if backed globally.
\end{abstract}

Keywords: Decarbonisation and the UNFCCC, the COP21 GOALS: I, II and III, renewables, Ouarzazate size solar parks

d) Fish harvest decrease;

e) Droughts and starvation;

f) Lack of fresh water supply;

g) Drying up of rivers, affecting electricity supply;

h) Ocean acidification and species extinction;

i) Highly volatile climate with storms, rainfall and tornados with tremendous damages;

j) Deforestation and desertification.

\section{INTRODUCTION}

The COP21 objectives are: GOAL I: Halt CO2 increases by 2018-2020; some countries already have done so, but far from all; GOAL II: Reduce CO2 emissions by 30-40 per cent at 2005 levels, depending on how counts, by 2030 - an immense challenge; GOAL III: Complete decarbonisation by 2070-75.

Considering the probable damages from global warming, it is astonishing that global warming theory has not been better recognized or even conceptually developed or empirically corroborated. There will be sooner or later:

a) Huge land losses along the costs;

b) Too high temperatures for men and women to work outside;

c) Food production decline;

This list is far from complete or exhaustive. One could even mention worse outcomes, like the transformations of warm and cold currents in the oceans - Gulf Stream, North Atlantic Current for example. What one may underline is that so far no known negative feedback has been found that could stem global warming naturally. We seem to have mainly only positive feedbacks, meaning outcomes reinforce each other in the same direction. The situation in the Amazons and Borneo is basically "lost", and Siberian forests threatened.

\section{GW THEORY}

French mathematician Joseph Fourier discovered global warming in the early $19^{\text {th }}$ century, but the theory was developed by Swedish chemist Arrhenius around 1895. He calculated that a doubling of CO2 ppm would be conducive to a 5 degree increase in global average temperature, which is not too far off the worst case scenario for the 21rst century, according to UN expertise now. 
Yet, it was not until Stephen Schneider published Global Warming in 1989 that the theory started to receive wide attention, no doubt strengthened by the work of Keeling in measuring $\mathrm{CO} 2$ ppm globally. Moreover, techniques for viewing the $\mathrm{CO} 2$ layer were developed, increasing the attention to climate change.

Now, the UN reacted with creating a few bodies to look into the changes going on, one of which was the COP framework. The economists jumped in besides the natural scientists, worried about the future costs of this transformation of the atmosphere. On the one hand, Kaya and associates presented in 1997 a model that explained $\mathrm{CO} 2$ :s with energy and energy intensity of GDP. On the other hand, Stern called global warming the largest externality in human history, calling for international governance in order to stem the growth of greenhouse gases. Stern outlined in 2007 a number of activities aimed at reducing CO2 emissions, promising also a Super Fund to channel money from rich advanced nations to poor countries and developing economies. As little has been done through the UN system of meetings and agencies transaction costs - up to date, Stern 2015 asked: "What are we waiting for?", neglecting his promise of the Super Fund (Ramesh, 2015).

The part of GWT analyzing the coordination efforts within the UNFCCC as well as the different country responses to climate change is far less developed than the natural sciences' part. One finds practically nothing in the UNFCCC documents about the principal problems in large scale international governance, like e.g. defection. One may speak of two currents of social science theory that are highly relevant for GWT:

\section{i) Implementation theory:}

In the discipline of public administration and policy-making, some ideas about the so-called "implementation gap" - Wildavsky's hiatus - are highly relevant to the COP21 project (Pressman and Wildavsky, 1973, 1984). The COP21 has three main objectives: halt $\mathrm{CO} 2$ increases by 2018-2020 (GOAL I), decrease CO2 emissions considerable by 2030 (GOAL II) and achieve full decarbonistion by 2070-80 (GOAL III).

But how are they to be implemented? No one knows, because COP21 has neglected what will happen after the major policy decision. The COP21 project outlines many years of policy implementation to reach decarbonisation, but which are the policy tools?

\section{ii) Game theory:}

A CPR is vulnerable to the strategy of reneging, as analysed theoretically in the discipline of game theory. The relevant game for the CPR is the PD game, where the sub game perfect Nash equilibrium is defection in a finite version of this game (Dutta, 1999). This is not recognized by Elinor Ostrom (1990) in her too optimistic view about the viability of CPR:s. It is definitely not the case that Ostrom has overcome Hobbes ("And covenants, without the sword, are but words and of no strength to secure a man at all'), as one commentator naively declared when she was awarded both the Nobel Prize and the Johan Skytte prize (Rothstein' website 2014).

The COP21 project houses lots of reneging opportunities of various sorts, which will become clear as this CPR project moves forward. One major partner has already defected, which may trigger other governments to renege. The only way to control defection in this global CPR is to employ selective incentives, which is what the planned Super Fund could offer, if at all workable.

\section{THE COP21: Implementation}

All forms of energy be measured, and these measures are translatable into each other - a major scientific achievement. One may employ some standard sources on energy consumption and what is immediately obvious is the immensely huge numbers involved see Table 1 .

\section{TABLE 1: Energy consumption 2015 (Million Tons of oil equivalent)}

\begin{tabular}{|l|l|l|}
\multicolumn{3}{|c|}{ Total \% } \\
\hline Fossil fuels & 11306,4 & $\mathbf{8 6 , 0}$ \\
\hline Oil & 4331,3 & 32,9 \\
\hline Natural Gas & 3135,2 & 23,8 \\
\hline Coal & 3839,9 & 29,2 \\
\hline Renewables & 1257,8 & $\mathbf{9 , 6}$ \\
\hline Hydroelectric & 892,9 & 6,8 \\
\hline Others & 364,9 & 2,8 \\
\hline Nuclear power & 583,1 & $\mathbf{4 , 4}$ \\
\hline Total & 13147,3 & $\mathbf{1 0 0 , 0}$ \\
\hline
\end{tabular}


Source: BP Statistical Review of World Energy 2016

It is true that a lot is happening with energy and emissions, but one tends to report only the positive news about coal reduction, more efficiency in energy consumption, new solar and wind plants. Sad to say, one bypasses the constantly increasing need for energy, the augmentation of air transportation, more cars and bigger engines, and first and foremost more human beings! The COP21 call for decarbonisation entails a sharp reduction of fossil fuels up until 2030 in order to stabilize climate change, involving a 30-40 decrease in $\mathrm{CO} 2$ emissions, measured against the 2005 level of emissions.
Let us first focus upon what this hoped for reduction of fossil fuels implies for the augmentation of renewable energy consumption, here solar power. The use of atomic power is highly contested, some countries closing reactors while others construct new and hopefully safer ones. I here bypass wind power and thermal power for the sake of simplicity in calculations.

Consider now Table 1, using the giant solar power station in Morocco as the benchmark - How many would be needed to replace the energy cut in fossil fuels and maintain the same energy amount, for a few selected countries with big $\mathrm{CO} 2$ emissions?

Table 1: Number of Ouarzazate plants necessary in 2030 for COP21's GOAL II: Global scene (Note: Average of 250 - 300 days of sunshine used for all entries except Australia, Indonesia, and Mexico, where 300 - 350 was used).

\begin{tabular}{|c|c|c|c|}
\hline Nation & $\begin{array}{c}\text { Co2 reduction } \\
\text { pledge / } \\
\text { \% of } 2005 \text { emissions }\end{array}$ & $\begin{array}{c}\text { Number of gigantic } \\
\text { solar plants needed } \\
\text { (Ouarzazate) }\end{array}$ & $\begin{array}{c}\text { Gigantic plants } \\
\text { needed for } \mathbf{4 0} \% \\
\text { reduction }\end{array}$ \\
\hline United States & $26-28^{\mathrm{i}}$ & 2100 & 3200 \\
\hline China & none $\mathrm{i}^{\mathrm{i}}$ & 0 & 3300 \\
\hline EU28 & $41-42$ & 2300 & 2300 \\
\hline India & none $^{\mathrm{ii}}$ & 0 & 600 \\
\hline Japan & 26 & 460 & 700 \\
\hline Brazil & 43 & 180 & 170 \\
\hline Indonesia & 29 & 120 & 170 \\
\hline Canada & 30 & 230 & 300 \\
\hline Mexico & 25 & 120 & 200 \\
\hline Australia & $26-28$ & 130 & 190 \\
\hline Russia & none & 0 & 940 \\
\hline World & N/A & N/A & 16000 \\
\hline
\end{tabular}

If countries rely to some extent upon wind or geothermal power or atomic power, the number in Table 1 will be reduced. The key question is: Can so much solar power be constructed in some 10 years? If not, Hawkins may be right. Thus, the COP23 should decide to embark upon an energy transformation of this colossal size.

Solar power investments will have to take many things into account: energy mix, climate, access to land, energy storage facilities, etc. They are preferable to nuclear power, which pushes the pollution problem into the distant future with other kinds of dangers. Wind power is accused to being detrimental to bird life, like in Israel's Golan Heights. Geo-thermal power comes from volcanic power and sites.

Let us look at the American scene in Table 2. 
International Journal of Trend in Scientific Research and Development (IJTSRD) ISSN: 2456-6470

Table 2: Number of Ouarzazate plants necessary in 2030 for COP21's GOAL II: American scene (Note: Average of 250 - 300 days of sunshine per year was used for Canada, 300 - 350 for the others).

\begin{tabular}{|l|l|l|l|}
\hline \multicolumn{1}{|c|}{ Nation } & \multicolumn{1}{|c|}{$\begin{array}{c}\text { Co2 reduction } \\
\text { pledge / } \\
\text { \% of 2005 } \\
\text { emissions }\end{array}$} & $\begin{array}{c}\text { Number of gigantic } \\
\text { solar plants needed } \\
\text { (Ouarzazate) }\end{array}$ & $\begin{array}{c}\text { Gigantic plants } \\
\text { needed for 40 \% } \\
\text { reduction }\end{array}$ \\
\hline Canada & 30 & 230 & 300 \\
\hline Mexico & 25 & 120 & 200 \\
\hline Argentina & none & 0 & 80 \\
\hline Peru & none $^{\text {ii }}$ & 0 & 15 \\
\hline Uruguay & none & 0 & 3 \\
\hline Chile & 35 & 25 & 30 \\
\hline
\end{tabular}

It has been researched has much a climate of Canadian type impacts upon solar power efficiency. In any case, Canada will need backs ups for its many solar power parks, like gas power stations. Mexico has a very favourable situation for solar power, but will need financing from the Super Fund, promised in COP21 Treaty. In Latin America, solar power is the future, especially as water shortages may be expected. Chile can manage their quota, but Argentine needs the Super Fund for sure.

Table 3 has the data for the African scene with a few key countries, poor or medium income..

Table 3: Number of Ouarzazate plants necessary in 2030 for COP21's GOAL II: African scene (Note: Average of 300 - 350 days of sunshine per year was used).

\begin{tabular}{|l|l|l|l|}
\hline \multicolumn{1}{|c|}{ Nation } & \multicolumn{1}{|c|}{$\begin{array}{c}\text { Co2 reduction } \\
\text { pledge / } \\
\text { \% of 2005 } \\
\text { emissions }\end{array}$} & $\begin{array}{c}\text { Number of gigantic } \\
\text { solar plants needed } \\
\text { (Ouarzazate) }\end{array}$ & $\begin{array}{c}\text { Gigantic plants } \\
\text { needed for 40 \% } \\
\text { reduction }\end{array}$ \\
\hline Algeria & $7-22^{\text {iv }}$ & 8 & 50 \\
\hline Egypt & none ${ }^{\text {ii }}$ & 0 & 80 \\
\hline Senegal & $5-21$ & 0,3 & 3 \\
\hline Ivory Coast & $28-36^{\text {iv }}$ & 2 & 3 \\
\hline Ghana & $15-45^{\text {iv }}$ & 1 & 3 \\
\hline Angola & $35-50^{\text {iv }}$ & 6 & 7 \\
\hline Kenya & $30^{\text {iv }}$ & 3 & 4 \\
\hline Botswana & $17^{\text {iv }}$ & 1 & 2 \\
\hline Zambia & $25-47^{\text {iv }}$ & 0,7 & 1 \\
\hline South Africa & none & 0 & 190 \\
\hline
\end{tabular}

Since Africa is poor, it does not use much energy like fossil fuels, except Maghreb as well as Egypt plus much polluting South Africa, which countries must make the energy transition as quickly as possible. The rest of Africa uses either wood coal, leading to deforestation, or water power. They can increase solar power without problems when helped financially.

Table 4 shows the number of huge solar parks necessary for a few Asian countries. The numbers are staggering, but can be fulfilled, if turned into the number ONE priority. Some of the poor nations need external financing and technical assistance. 
International Journal of Trend in Scientific Research and Development (IJTSRD) ISSN: 2456-6470

Table 4: Number of Ouarzazate plants necessary in 2030 for COP21's GOAL II. Asian scene (Note: Average of 250 - 300 days of sunshine was used for Kazakhstan, 300 - 350 days of sunshine per year for the others).

\begin{tabular}{|l|l|l|l|}
\hline \multicolumn{1}{|c|}{ Nation } & \multicolumn{1}{|c|}{$\begin{array}{c}\text { Co2 reduction } \\
\text { pledge / } \\
\text { \% of 2005 } \\
\text { emissions }\end{array}$} & $\begin{array}{c}\text { Number of gigantic } \\
\text { solar plants needed } \\
\text { (Ouarzazate) }\end{array}$ & $\begin{array}{c}\text { Gigantic plants } \\
\text { needed for 40 \% } \\
\text { reduction }\end{array}$ \\
\hline Saudi Arabia & none & 0 & 150 \\
\hline Iran & $4-12^{\mathrm{iv}}$ & 22 & 220 \\
\hline Kazakhstan & none & 0 & 100 \\
\hline Turkey & 21 & 60 & 120 \\
\hline Thailand & $20-25^{\mathrm{ii}}$ & 50 & 110 \\
\hline Malaysia & none & 0 & 80 \\
\hline Pakistan & none & 0 & 60 \\
\hline Bangladesh & 3,45 & 2 & 18 \\
\hline
\end{tabular}

Finally, we come to the European scene, where also great investments are needed, especially as nuclear power is reduced significantly and electrical cars will replace petrol ones, to a large extent.

Table 4: Number of Ouarzazate plants necessary in 2030 for COP21's GOAL II: European scene (Note: Average of 250 - 300 days of sunshine per year was used)

\begin{tabular}{|l|l|l|l|}
\hline \multicolumn{1}{|c|}{ Nation } & \multicolumn{1}{|c|}{$\begin{array}{c}\text { Co2 reduction } \\
\text { pledge / } \\
\text { \% of 2005 } \\
\text { emissions }\end{array}$} & $\begin{array}{c}\text { Number of gigantic } \\
\text { solar plants needed } \\
\text { (Ouarzazate) }\end{array}$ & $\begin{array}{c}\text { Gigantic plants } \\
\text { needed for 40 \% } \\
\text { reduction }\end{array}$ \\
\hline Germany & $49^{\mathrm{v}}$ & 550 & 450 \\
\hline France & $37^{\mathrm{v}}$ & 210 & 220 \\
\hline Italy & $35^{\mathrm{v}}$ & 230 & 270 \\
\hline Sweden & $42^{\mathrm{v}}$ & 30 & 30 \\
\hline
\end{tabular}

Is there space to build all these solar parks, one may ask. But many, many small houses with solar roofs will also do well. Public buildings and company offices may be run on solar power from their roofs! Innovation is needed everywhere.

As the Keeling curve continues its relentless rise (Earth CO2), we must take Hawkins warning about irreversibility seriously. Moving now and up to 2030, according to the COP21's GOAL II for decarbonisation eliminates irreversibility. The solution is solar power parks of Ouarzazate type size. Above is a calculation of what is needed in many countries around the world, taking into account the insights of the research into GDP-energy-emission links. Time has come for halting and reducing $\mathrm{CO} 2$ emissions by real implementation and not utopian dreams of a sustainable economy (Sachs, 2015). There is nothing to wait for any longer (Stern, 2015), as the COP23 must set of the promised Super Fund. No time for politicking in the UN any longer (Conca, 2015; Vogler, 2016).

\section{CONCLUSION}

When Stephen Hawking starts to talk about climate change irreversibility, then the world must listen. If $\mathrm{CO} 2$ emissions continue to rise on the Keeling curve (Earth CO2), then temperature could go towards a 4-6 increase. Everything would be affected negatively all social systems, the economy, all living organisms. This goal of avoiding irreversibility is more important for mankind than North Korea's aggression, the South China Sea, the new Silk Road, Brexit and the civil 
war in the Muslim civilization. To stop global warming, huge investments in solar power parks are necessary. It will be costly but eminently wothwile.

\section{REFERENCES}

\section{SOURCES}

\section{Solar power}

1) Paris 2015: Tracking country climate pledges. Carbon Brief, https://www.carbonbrief.org/paris2015-tracking-country-climate-pledges

2) EDGAR v 4.3.2, European Commission, Joint Research Centre (JRC)/PBL Netherlands Environmental Assessment Agency. Emission Database for Global Atmospheric Research (EDGAR), release version 4.3.2. http://edgar.jrc.ec.europe.eu, 2016 forthcoming

3) $\mathrm{CO} 2$ Emission Reduction With Solar http://www.solarmango.com/in/tools/solarcarbon-emission-reduction

\section{GDP sources:}

4) World Bank national accounts data data.worldbank.org

5) OECD National Accounts data files

\section{GHG and energy sources:}

6) World Resources Institute CAIT Climate Data Explorer - cait.wri.org

7) EU Joint Research Centre Emission Database for Global Atmospheric

8) Research http://edgar.jrc.ec.europa.eu/overview.php

9) UN Framework Convention on Climate Change http://unfecc.int/ghg_data/ghg_data_unfccc/ti me_series_annex_i/items/3814.php

10) International Energy Agency. Paris.

11) Energy Information Administration. Washington, DC.

12) BP Energy Outlook 2016.

13) EU Emissions Database for Global Research EDGAR, http://edgar.jrc.ec.europa.eu/

14) World Bank Data Indicators, data.worldbank.org

15) British Petroleum Statistical Review of World Energy 2016.

\section{Literature}

16) "Arrhenius, Svante August" in Chambers's Encyclopædia. London: George Newnes, 1961, Vol. 1.

17) Barry, B. (1982) "The Tradition of Spontaneous Order", in Literature of Liberty. Vol. V, No. 2, pp. 7-58. Arlington, VA: Institute for Humane Studies.

18) Conka, K. (2015) Un Unfinished Foundation. The United Nations and Global Environmental Governance. Oxford: OUP.

19) Dutta, P.L. (1999) Strategies and games. Cambridge, MA: MIT Press.

20) Hayek, F.A. (1991) The Fatal Conceit: The Errors of Socialism. Chicago: The University of Chicago Press.

21) Kaya, Y., and Yokoburi, K. (1997) Environment, energy, and economy: Strategies for sustainability. Tokyo: United Nations University Press.

22) Ramesh, J. (2015) Green Signals: Ecology, Growth and Democracy in India (2015). Oxford : Oxford University Press.

23) Sachs, J.D. (2015) The Age of Sustainable Development. New York: Columbia University Press.

24) Stern, N. (2007) The Economics of Climate Change. Oxford: OUP.

25) Stern, N. (2015) What are we waiting for? Cambridge, MA: MIT Press.

26) Vogler, J. (2016) Climate Change in World Politics. Basingstoke: MacmillanPalgrave

\section{NOTES}

\footnotetext{
i The United States has pulled out of the deal

' No absolute target

'Pledge is above current level, no reduction

i Upper limit dependent on receiving financial support

' EU joint pledge of $40 \%$ compared to 1990
} 
